\title{
Characterization of T Cell Repertoire in Patients with Graft-Versus-Leukemia After Donor Lymphocyte Infusion
}

\author{
Emmanuel J. Claret, ${ }^{*}$ Edwin P. Alyea, ${ }^{*}$ Enrica Orsini, ${ }^{*}$ Christopher C. Pickett, ${ }^{*}$ Heather Collins, ${ }^{*}$ Yulan Wang, ${ }^{*}$ \\ Donna Neuberg, ${ }^{\ddagger}$ Robert J. Soiffer, ${ }^{*}$ and Jerome Ritz* \\ $*$ Division of Hematologic Malignancies and ${ }^{\ddagger}$ Division of Biostatistics, Dana-Farber Cancer Institute, Department of Medicine, Harvard \\ Medical School, Boston, MA 02115
}

\begin{abstract}
The clinical efficacy of donor lymphocyte infusions (DLI) in patients with relapsed chronic myelocytic leukemia after allogeneic bone marrow transplantation has been demonstrated in several recent studies. Although it is presumed that allogeneic $T$ cells mediate this graft-versus-leukemia (GVL) effect, the influence of DLI on the T cell compartment of recipients has not been determined. To characterize the immunologic effects of DLI and to identify T cell changes selectively associated with the GVL response, we analyzed the $T$ cell receptor (TCR) repertoire in four patients with relapsed chronic myelocytic leukemia who achieved a complete remission after infusion of CD4+ lymphocytes from HLA-identical sibling donors. Only one of the four patients developed clinically significant graft-versus-host disease (GVHD) after infusion of donor lymphocytes. TCR repertoire was examined after PCR amplification of $24 \mathrm{~V} \beta$ gene subfamilies in serial samples obtained over a 1-yr period before and after DLI. Results were compared to 10 normal donors. Before DLI, all four patients were found to have abnormal TCR V $\beta$ repertoire in peripheral T cells, associated with a large number of clonal and oligoclonal patterns. Abnormal TCR patterns persisted for at least 3 mo after DLI, but thereafter gradually began to normalize. By $1 \mathrm{yr}$ after DLI, all patients demonstrated almost complete normalization of $\mathrm{V} \beta$ repertoire with polyclonal representation within almost all $\mathrm{V} \beta$ gene subfamilies. We also examined changes in the TCR V $\beta$ repertoire associated with the disappearance of $\mathrm{Ph}+$ cells. In each patient, we were able to identify the expansion of at least $1 \mathrm{~V} \beta$ gene subfamily that coincided with the time of the cytogenetic response. In one patient who was studied in greater detail, CDR3 size analysis of serial samples after DLI indicated that these changes were associated with the appearance of clonal $T$ cells. This finding was confirmed through CDR3 sequence analysis and use of CDR3 clone-specific oligonucleotide probes. A putative GVL clone identified by this technique was not detectable in either donor or patient $\mathrm{T}$ cells before DLI, but persisted in peripheral $\mathrm{T}$ cells for $\sim 1 \mathrm{yr}$. These experiments therefore provide
\end{abstract}

Address correspondence to Jerome Ritz, M.D., Division of Hematologic Malignancies, Dana-Farber Cancer Institute, 44 Binney St., Boston, MA 02115. Phone: 617-632-3465; FAX: 617-632-5167; E-mail: jerome_ritz@dfci.harvard.edu

Received for publication 26 December 1996 and accepted in revised form 19 May 1997.

J. Clin. Invest.

(c) The American Society for Clinical Investigation, Inc. 0021-9738/97/08/0855/12 \$2.00

Volume 100, Number 4, August 1997, 855-866

http://www.jci.org evidence for the clonal expansion of allogeneic $T$ cells that may be selective mediators of antileukemia activity without also mediating graft-versus-host disease. (J. Clin. Invest. 1997. 100:855-866.) Key words: T cell receptor $\bullet T$ cell repertoire - chronic myelocytic leukemia - allogeneic bone marrow transplantation - donor lymphocyte infusion - CD4 lymphocyte

\section{Introduction}

Adoptive cellular therapy has recently been demonstrated to provide effective treatment for patients who relapse after allogeneic bone marrow transplantation $(\mathrm{BMT})^{1}(1-6)$. Clinical responses to donor lymphocyte infusion (DLI) are seen most often in patients with chronic myelogenous leukemia (CML) with $\sim 60-80 \%$ of patients achieving a complete hematologic response $(1,3,6,7)$. The majority of these patients no longer have CML cells detectable by either cytogenetic evaluation or more sensitive assessment of minimal residual disease using molecular detection methods. Responses occur less frequently in patients with relapsed blast crisis CML as well as relapsed acute leukemias $(1,3,6)$.

The ability of DLI to eliminate leukemia cells in vivo confirms the important role played by donor lymphocytes in the eradication of residual leukemia cells after allogeneic BMT. Several clinical observations have previously provided indirect evidence in support of this graft-versus-leukemia (GVL) effect (8). These observations have included the demonstration that recipients of either syngeneic or autologous marrow have a higher risk of relapse after BMT than do recipients of allogeneic marrow $(8,9)$, and that depletion of $\mathrm{T}$ cells from the donor marrow is also associated with a higher risk of relapse $(10$, 11). It has also been shown that patients with graft-versus-host disease (GVHD) after BMT have a lower risk of relapse (1214), and this observation has led to the hypothesis that both GVHD and GVL are similar, if not identical, immunologic effects (8). Although a variety of immune mechanisms play important roles in GVHD and GVL, data derived from both animal models and clinical experience suggest that both effects are primarily mediated by donor $\mathrm{T}$ cells $(15,16)$.

In almost all clinical trials of DLI, peripheral blood lymphocytes are obtained from the same HLA-identical donor that had previously donated marrow and infused into the marrow recipient without further in vitro manipulation. As expected, infusion of large numbers of allogeneic $\mathrm{T}$ cells frequently results in significant GVHD, which is the most common serious toxicity associated with DLI occurring in 40-

1. Abbreviations used in this paper: BMT, bone marrow transplantation; CML, chronic myelocytic leukemia; DLI, donor lymphocyte infusions; GVHD, graft-versus-host disease; GVL, graft-versus-leukemia; TCR, T cell receptor. 
$60 \%$ of patients. The majority of patients who achieve remission after infusion of donor lymphocytes also develop GVHD, but occasional patients have demonstrated responses without concomitant GVHD $(3,4,6)$. To limit the toxicity of DLI, we and others have examined different strategies to limit the induction of GVHD. MacKinnonn et al. (17) demonstrated that the incidence of GVHD could be reduced by limiting the total number of allogeneic $T$ cells infused. Clinical trials reported by Giralt et al. (18) and Alyea et al. (manuscript in preparation) have suggested that depletion of CD8+ T cells also effectively reduces the incidence of GVHD associated with infusion of unfractionated $\mathrm{T}$ cells. Interestingly, both approaches appear to be effective in reducing the toxicity associated with DLI without also eliminating the concomitant antileukemia effect. The results of these clinical trials therefore suggest that it may be possible to distinguish GVHD from GVL, even though both immunologic effects appear to be mediated by allogeneic T lymphocytes $(16,19)$.

To characterize the effects of DLI on the T cell population in the recipient, and to identify changes in T cells that may be associated with the antileukemic effects of DLI, we undertook a serial analysis of $\mathrm{T}$ cell receptor (TCR) repertoire in four patients with relapsed CML who received selective infusions of CD4+ donor T cells. All four patients achieved complete cytogenetic and molecular remission after DLI, but only one of the four patients developed clinically significant GVHD requiring immune suppressive therapy. TCR repertoire was examined after PCR amplification of 24 distinct V $\beta$ subfamily genes (20) in blood samples obtained over a 1-yr period, and results were compared to 10 normal donors. This method, which allows examination of the relative use of each V $\beta$ gene subfamily as well as the identification of clonal and oligoclonal T cell populations in each sample, has previously been used to identify clonal $\mathrm{T}$ cell expansions in a variety of clinical circumstances, including GVHD lesions (21-25), graft rejection (26), and in the early period of reconstitution after allogeneic BMT (27). These experiments demonstrated that the $\mathrm{T}$ cell population was abnormal in each patient before DLI, and that the $\mathrm{T}$ cell repertoire gradually normalized during the 1-yr observation period in every patient. Moreover, we have also identified individual V $\beta$ subfamilies that appear to expand in vivo at the time of clinical response in each patient, suggesting a relationship between these $\mathrm{T}$ cells and the elimination of leukemic cells in vivo.

\section{Methods}

CD4+ donor lymphocyte infusions. Serial blood samples for the in vitro experiments described in this report were obtained from four patients with CML in clinical or cytogenetic relapse after allogeneic BMT. Each patient (described individually below and in Table I) was enrolled in a clinical trial of allogeneic lymphocyte infusions to evaluate the toxicity and immunologic effects of escalating doses of CD4+ $\mathrm{T}$ cells. Donor $\mathrm{T}$ cells were obtained by lymphopheresis from the same HLA-identical sibling that had previously donated marrow for allogeneic BMT. Mononuclear cells were isolated from the lymphopheresis product by Ficoll/Hypaque density gradient centrifugation, and CD4+ T cells were obtained after depletion of mononuclear cells by two sequential incubations with anti-CD8 monoclonal antibody and rabbit complement as previously described for $\mathrm{T}$ cell depletion of donor marrow (28). After completion of CD8 depletion and three washes to remove remaining antibody and complement, the total number of $\mathrm{CD} 4+$ cells was determined by enumerating the percent cells reactive with anti-CD4-PE (Coulter Corp., Miami, FL) by flow cytometric analysis (ELITE; Coulter Corp.). Patients described in this report received either $3 \times 10^{7}$ or $1.5 \times 10^{8} \mathrm{CD} 4+$ cells $/ \mathrm{kg}$. DLI contained $<1 \%$ CD8 $+\mathrm{T}$ cells. DLI was repeated at weekly intervals until the targeted number of CD4 $+\mathrm{T}$ cells were administered. For patients receiving $\alpha$-interferon, therapy was discontinued before DLI, and patients received no other immune-stimulating therapy after DLI. The clinical research protocol for this trial was approved by the Human Subjects Protection Committee of the Dana-Farber Cancer Institute, and informed consent was obtained from each patient and donor. Blood samples for TCR V $\beta$ analysis were obtained before DLI, at 1-mo intervals for $6 \mathrm{mo}$, and at 3-mo intervals for 6 mo in the first year after DLI. All four patients in this analysis have been followed for at least $2 \mathrm{yr}$ after DLI.

Patient histories. The clinical characteristics of the four patients studied in this report are summarized in Table I. Each patient underwent allogeneic BMT for stable-phase CML, and received marrow from HLA-identical sibling donors. In each case, donor marrow had been depleted of CD6-positive T cells as previously described (28), and patients received no other immune suppressive therapy to prevent GVHD after BMT. Complete hematopoietic engraftment with donor cells was documented in each patient, and none developed acute or chronic GVHD after BMT.

Patient 1 is a 52-yr-old male who first underwent allogeneic BMT in 1986. He relapsed $2 \mathrm{yr}$ after transplant, and remained in a second stable phase until 1991 when he developed accelerated CML and underwent a second CD6 T cell-depleted BMT. His second donor was another HLA-identical male sibling. He developed a cytogenetic relapse in July 1992 and progressed to hematologic relapse in October 1993. In May 1994 he received $0.3 \times 10^{8} \mathrm{CD} 4+$ donor T cells $/ \mathrm{kg}$ after in vitro depletion of CD8+ cells as described above. $10 \mathrm{wk}$ after DLI, the patient developed pancytopenia, which resolved spontaneously within 1 wk. Coincident with hematologic recovery, no $\mathrm{Ph}+$ metaphases were noted by cytogenetic evaluation, and BCR-ABL+ cells were no longer detectable by reverse transcription PCR assay using nested primers as described previously $(29,30)$. With $21 / 2$ yr followup, the patient remains in complete cytogenetic and molecular remission.

Patient 2 is a 55-yr-old female who underwent allogeneic BMT in October 1990. She developed a cytogenetic relapse in January 1993 and subsequently progressed to a second stable-phase CML. She received CD8-depleted donor lymphocytes $\left(0.3 \times 10^{8} \mathrm{CD} 4+\right.$ cells $\left./ \mathrm{kg}\right)$ in June 1994. Beginning 2 mo after DLI, a slow decline in white blood cell count was noted. The patient achieved a cytogenetic remission in November 1994 but remained pancytopenic with a hypocellular marrow requiring transfusion support. 6 mo after DLI, the patient received an infusion of CD6 T cell-depleted bone marrow from the same donor without further chemotherapy. Blood counts subsequently recovered. In March 1995 BCR-ABL-positive cells were no longer detectable by PCR. With follow-up of 23 mo the patient remains in cytogenetic and molecular remission.

Patient 3 is a 57-yr-old female who underwent allogeneic BMT in November 1993. In December 1994 she was found to have a cytogenetic relapse. She received CD8-depleted donor lymphocytes $(1.5 \times$ $10^{8} \mathrm{CD} 4+$ cells $/ \mathrm{kg}$ ) in May 1995 . A complete cytogenetic response was noted by July 1995 . She also developed liver function abnormalities consistent with acute GVHD, and later developed skin abnormalities characteristic of limited chronic GVHD. Hepatic and skin GVHD responded to prednisone. BCR-ABL-positive cells were no longer detectable by PCR in January 1996. With 1-yr follow-up after DLI she remains in cytogenetic remission without evidence of BCR$\mathrm{ABL}+$ cells detectable by PCR.

Patient 4 is a 34 -yr-old female who underwent allogeneic BMT in November 1990. 6 mo after transplant she was noted to have a cytogenetic relapse. She responded to $\alpha$-interferon and achieved a cytogenetic remission, but again progressed when $\alpha$-interferon was discontinued. She received CD8-depleted donor lymphocytes in April 1995 $\left(1.5 \times 10^{8} \mathrm{CD} 4+\right.$ cells $\left./ \mathrm{kg}\right)$, and achieved a complete cytogenetic re- 
sponse by July 1995 but did not become PCR-negative for BCRABL + cells until April 1996. Although this patient had no evidence of acute GVHD after DLI, she developed mild symptoms of dry eyes and dry mouth which resolved without therapy, and likely represented minimal chronic GVHD.

$R N A$ extraction, reverse transcription, and PCR. Heparinized blood samples were obtained prospectively from patients receiving CD4+ DLI at specific intervals as well as from their normal HLA-identical sibling donors. PBMC were isolated by Ficoll/Hypaque density gradient centrifugation. T lymphocytes were enriched from PBMC by immunomagnetic selection of CD3 + cells (MACS beads; Miltenyi Biotech, Auburn, CA).

RNA was extracted from $\mathrm{T}$ cell preparations (RNAStat-60 kit; Tel-test Inc., Friendswood, TX) according to the manufacturer's protocol. First-strand cDNA was generated from $2 \mu \mathrm{g}$ of total RNA using random hexanucleotides (Pharmacia LKB Biotechnology Inc., Piscataway, NJ) and reverse transcriptase (Superscript; GIBCO BRL, Gaithersburg, MD). Each V $\beta$ segment was amplified with one of the $24 \mathrm{~V} \beta$ subfamily-specific primers previously described and a $\mathrm{C} \beta$ primer recognizing both $\mathrm{C} \beta 1$ and $\mathrm{C} \beta 2$ regions $(31,32)$. PCR amplification of $\mathrm{V} \beta 5$ and $\mathrm{V} \beta 13$ each required the use of two sets of primers to identify the entire $\mathrm{V} \beta$ subfamily. The $C \beta$ primer was conjugated to fluorescent dye 6-FAM (Applied Biosystems, Inc., Foster City, CA) for CDR3 size analysis.

Quantitation of $V \beta$ subfamily representation in peripheral blood $T$ cells. $25 \mu \mathrm{l}(1 / 4)$ of each PCR reaction was electrophoresed on a $2 \%$ agarose gel, and blotted to nylon membranes (Boehringer Mannheim, Mannheim, Germany). The membrane was hybridized at $42^{\circ} \mathrm{C}$ overnight with a $\left[{ }^{32} \mathrm{P}\right] \gamma$-ATP-labeled $\mathrm{C} \beta$ internal probe $\left(5^{\prime}\right.$-GAGGACCTGAACAAGGTGTTCCCACCCGAG-3'). The membrane was exposed to a Phosphor screen, and the radioactive intensity of each specific band was quantified (PhosphorImager using ImageQuant software; Molecular Dynamics, Sunnyvale, CA). Representation of each $V \beta$ subfamily was calculated as a percentage of the sum of all $\mathrm{V} \beta$ signals detected on the autoradiogram.

$T$ cell receptor $\beta$ chain CDR3 fragment size analysis. The size distribution of each fluorescent PCR product was determined by electrophoresis on an automated 373 DNA sequencer (Applied Biosys- tems) using a $5.5 \%$ polyacrylamide gel, and data was analyzed by GeneScan software (Perkin Elmer Cetus Instruments, Emeryville, CA). Since the position of the $5^{\prime}$ and $3^{\prime}$ primers are fixed, fragment size differences within each V $\beta$ subfamily are entirely due to different CDR3 lengths, reflecting junctional diversity and $N$-random nucleotide insertions in the V-D-J region. Peaks corresponding to in-frame transcripts are detected at three nucleotide intervals. As described previously (33-36), a normal transcript size distribution, reflecting polyclonal cDNA contains $8-10$ peaks for each $\mathrm{V} \beta$ subfamily. The appearance of dominant peaks indicates the presence of excess cDNA of identical size, suggesting the presence of an oligoclonal or clonal $\mathrm{T}$ cell population. The absence of any peaks after PCR amplification suggests the absence of any $\mathrm{T}$ cells using a specific $\mathrm{V} \beta$ subfamily of TCR genes.

$T C R V \beta$-chain gene sequencing. TCR $\mathrm{V} \beta$ gene transcripts were amplified as described above, and the PCR product was purified (Wizard PCR preps kit; Promega Corp., Madison, WI) and ligated into the pCR2.1 TA cloning vector (Invitrogen Corp., San Diego, $\mathrm{CA})$. The ligation product was transfected into $\mathrm{INV} \alpha \mathrm{F}^{\prime}$-competent cells (Invitrogen Corp.). White growing colonies were randomly picked, checked for insert, and sequenced using standard methods.

Dot blot assay with CDR3- specific primers. The following oligonucleotide was synthesized for the CDR3 sequence of the expanded $\mathrm{V} \beta 15$ clone in patient 1 , and was conjugated with $\left[{ }^{32} \mathrm{P}\right] \gamma$-ATP: GATGGGGTTTTTGAAAAACTGTTT. cDNA from different samples was amplified with the V $\beta 15$-specific primer set, and aliquots of the amplified products were blotted onto nylon membranes, prehybridized, and hybridized overnight with the labeled probes at $42^{\circ} \mathrm{C}$ and $55^{\circ} \mathrm{C}$, respectively. Hybridization with the internal $\mathrm{C} \beta$ probe was also performed on the same samples as a positive control. Blots were washed twice at $4^{\circ} \mathrm{C}$ for $30 \mathrm{~min}$ in $6 \times \mathrm{SSC}$, and twice at $65^{\circ} \mathrm{C}$ for 20 min in TMAC. Signals were scanned using ImageQuant software (Molecular Dynamics).

Statistical methods. The significance of differences in the frequency of $\mathrm{V} \beta$ gene expression between normal $\mathrm{T}$ cells and patient $\mathrm{T}$ cells was determined by calculation of $Z$ scores. We assume that the frequency of $\mathrm{V} \beta$ gene expression follows a Gaussian distribution. Mean and standard deviation were obtained for use of $26-\mathrm{V} \beta$ gene

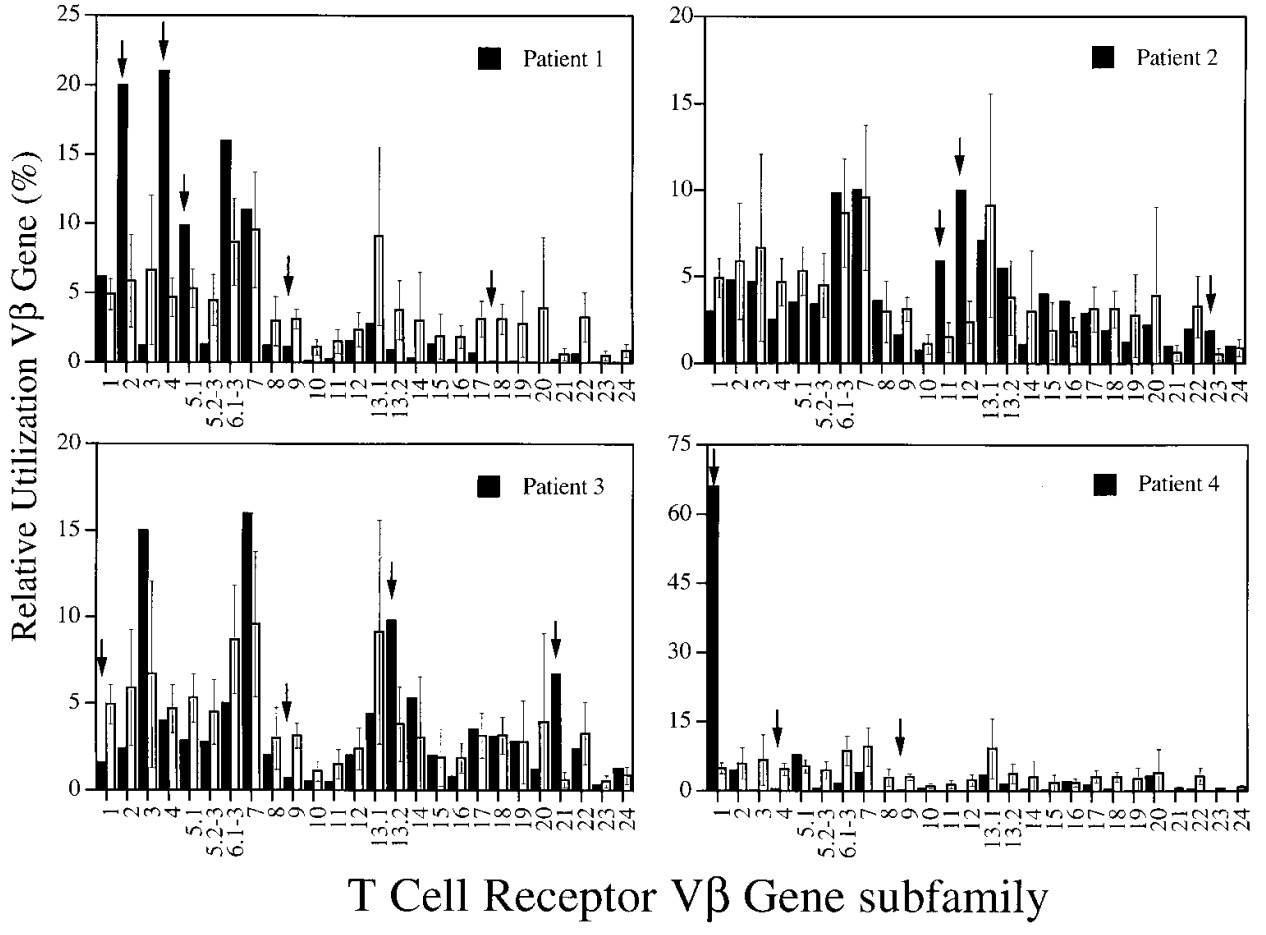

Figure 1. TCR V $\beta$ gene representation before $\mathrm{CD} 4+$ donor lymphocyte infusion. Use of $24 \mathrm{TCR} V \beta$ gene subfamilies was evaluated in T cells obtained from four patients with relapsed CML after allogeneic BMT. Results in each patient before donor lymphocyte infusion (black bars) are compared to results in 10 normal donors (white bars represent mean $\pm \mathrm{SD})$. Arrows indicate statistically significant $(P<0.01)$ differences between each patient and the group of normal donors. 


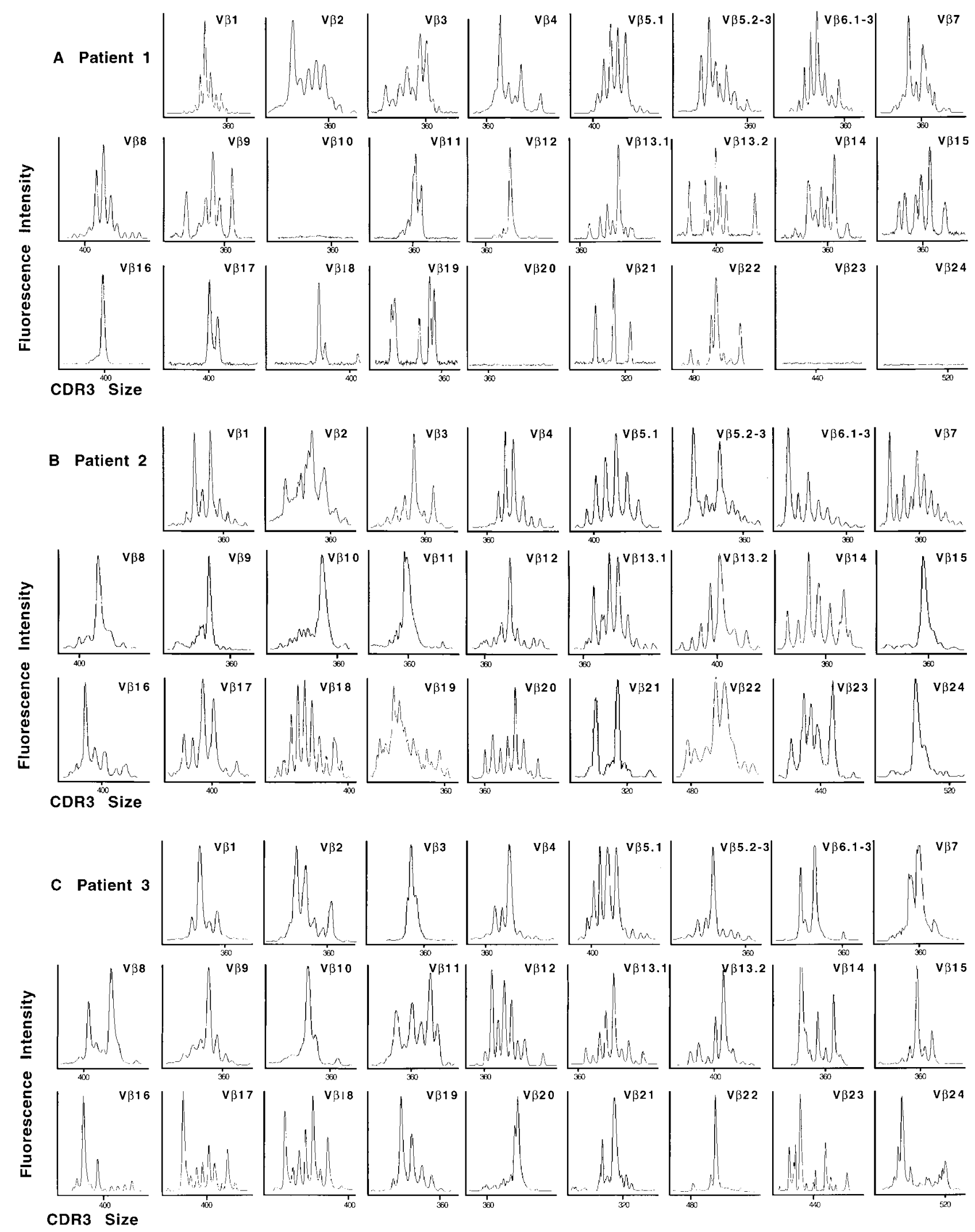

Figure 2. CDR3 size patterns in CD3 + T cells from patients and representative normal donor. CDR3 size distribution profiles were determined for each of 24 TCR V $\beta$ subfamilies in CD3 + T cells from the four patients depicted in Fig. 1 before donor lymphocyte infusion $(A-D)$. $E$ illustrates the same CDR3 profiles in a representative normal donor. Each PCR reaction was performed in the presence of a V $\beta$ subfamily-specific primer and a common fluorescent $C \beta$ primer recognizing both $C \beta 1$ and $C \beta 2$ regions. PCR products were run through sequencing gels and analyzed on an automated DNA sequencer using GeneScan software (Perkin-Elmer Corp., Norwalk, CT). Fluorescence intensity (y-axis) is plotted against CDR3 size ( $\mathrm{x}$-axis). 

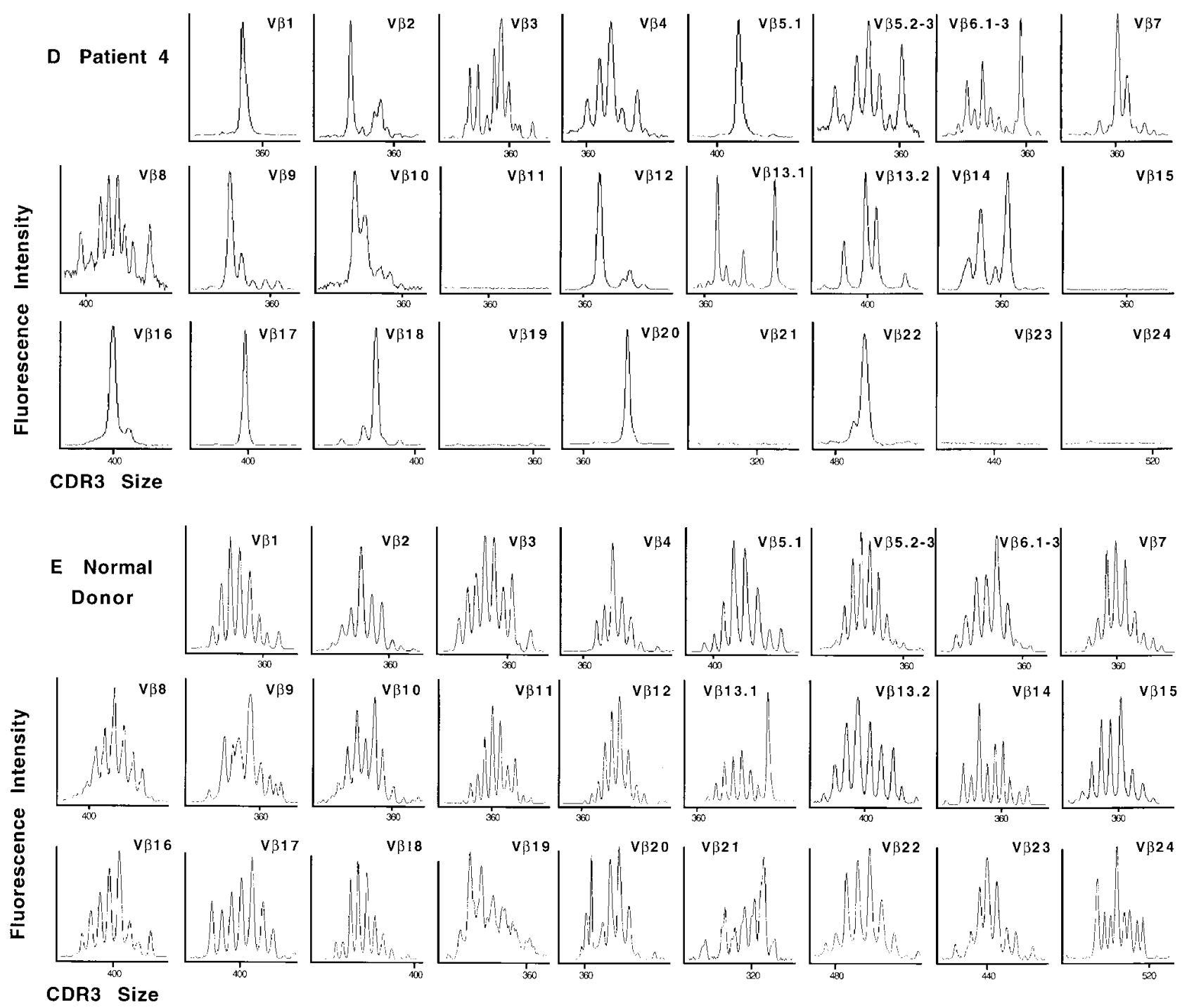

Figure 2 (Continued)

segments in normal $\mathrm{T}$ cells from 10 normal individuals. V $\beta$ gene segment usage in patient $\mathrm{T}$ cells was normalized using these reference values, and the resulting standardized value compared to the distribution of a Gaussian distribution with a mean of 0 and a standard deviation of 1 . We characterized $\mathrm{V} \beta$ gene usage which was more than 2.58 standard deviations from the normal mean as abnormal. Under the Gaussian assumption, $1 \%$ of all such normal standardized values would be classified as abnormal.

\section{Results}

$T C R V \beta$ gene use before donor lymphocyte infusion. To identify the effects of DLI on T cell repertoire, TCR V $\beta$ gene use was first analyzed before DLI in T cells obtained from four patients with chronic myelocytic leukemia in clinical or cytogenetic relapse after allogeneic BMT. Fig. 1 illustrates the relative use of individual TCR V $\beta$ genes in each of these four patients compared to results obtained from the identical analysis of 10 normal donors. In normal individuals, all 24 TCR V $\beta$ subfamilies are represented, and few, if any, $\mathrm{V} \beta$ subfamilies are represented in more than $15 \%$ of T cells. As shown in Fig. 1 , all four patients displayed a skewed TCR V $\beta$ gene use. The arrows in each panel indicate $\mathrm{V} \beta$ subfamilies that are statistically different $(P<0.01)$ from the group of normal donors $(\mathrm{Z}$ scores). Each patient profile is characterized by the presence of one or more abnormally expanded V $\beta$ subfamilies, as well as by complete absence or significant decrease of other V $\beta$ subfamilies. In some cases, individual V $\beta$ subfamily genes represented $20-65 \%$ of the T cell population. Overall, $14 \%$ of the TCR V $\beta$ gene repertoire was abnormally represented in these four patients before DLI. Using the same criteria, only $0.4 \%$ of the of the TCR V $\beta$ genes were abnormally represented in blood samples from the 10 normal donors.

In conjunction with analysis of expression of the 24 TCR $\mathrm{V} \beta$ subfamilies, we also determined the size spectrum of the CDR3 region for each V $\beta$ subfamily obtained after PCR amplification. In addition to characterizing TCR V $\beta$ gene segment use, this analysis provides an indication of clonal expansion within each V $\beta$ subfamily. Fig. $2, A-D$ shows the CDR3 size analysis of each $\mathrm{V} \beta$ subfamily derived from $\mathrm{T}$ cells before 
DLI in each patient. Results of a similar analysis in a normal HLA-identical donor (for patient 1) are shown for comparison in Fig. $2 E$. In normal donor T cells, the analysis of CDR3 size for each $V \beta$ gene demonstrates a Gaussian distribution of six to eight peaks, indicating the predominance of polyclonal $\mathrm{T}$ cells. Occasional oligoclonal peaks are identified in normal donors (e.g., V $\beta 13.1$ ); the V $\beta$ CDR3 patterns from all four patients display numerous oligoclonal and clonal populations. These clonal populations are identified as individual predominant peaks that alter the normal distribution profile. DNA sequence of the single peak CDR3 profiles such as V $\beta 1$ and V $\beta 5.1$ (patient 4) confirm that these peaks represent a single dominant transcript (data not shown). Some CDR3 profiles could not be analyzed because of the very low number of transcripts present, and the resulting inability to obtain sufficient PCRamplified product. Overall, 56\% of the CDR3 patterns were abnormal. Patient 4 presented the highest number of abnormal profiles, with 21 of $26(81 \%)$ of the V $\beta$ CDR3 patterns being abnormal. Clonal CDR3 patterns have previously been identified in normal individuals (36), but overall, fewer than $5 \%$ of the CDR3 profiles in our normal donors demonstrated predominant clonal $\mathrm{T}$ cell populations.

Simultaneous analysis of relative TCR V $\beta$ gene segment use (Fig. 1) and CDR3 size distribution (Fig. 2) provides substantial evidence that peripheral blood $\mathrm{T}$ cells from patients before DLI include an abnormally large number of clonal and oligoclonal $\mathrm{T}$ cell populations which, in cases illustrated by $\mathrm{V} \beta 3$ in patient 3 and $\mathrm{V} \beta 1$ in patient 4 , are markedly expanded in vivo.

Evolution of clonal T cell populations after donor lymphocyte infusion. After DLI, TCR V $\beta$ subfamily representation and V $\beta$ CDR3 profiles were characterized in serial blood samples obtained from the same four patients over a 1-yr period. Fig. 3 illustrates the changes observed in three representative TCR V $\beta$ gene subfamilies from patients 1 and 2 . Results obtained before DLI are compared to results within $48 \mathrm{~h}$ after DLI (postinfusion sample) and at periodic intervals for $1 \mathrm{yr}$ after infusion. Shortly after infusion of CD4+ donor lymphocytes, only minor changes in each patient's TCR V $\beta$ repertoire were noted, and each sample was characterized by the same overexpressed clonal $\mathrm{T}$ cell populations, as well as underrepresented V $\beta$ use that were present before DLI. Subsequent samples demonstrated decreased use of some $V \beta$ subfamilies as well as increased expression of other $\mathrm{V} \beta$ subfamilies (data not shown). These changes in relative use of TCR V $\beta$ gene subfamilies did not, however, always correlate with the clonal status of the T cell population as detected by the CDR3 size analysis. As shown in Fig. 3, several of these clonal profiles (patient 2: V $\beta 9$ and $\mathrm{V} \beta 15$; patient $1: \mathrm{V} \beta 12$ and $\mathrm{V} \beta 16$ ) persisted for 3 mo after DLI. Normal polyclonal CDR3 patterns began to replace oligoclonal and clonal CDR3 profiles beginning at $\sim 3$ mo in some instances (patient 2: V $\beta 12$ ), and gradually became more frequent at 6 mo after DLI (patient 2: V 39 and V $\beta 15$; patient 1: V $\beta 16)$. Similar results were noted in all four patients.

Normalization of TCR V $\beta$ repertoire and CDR3 patterns after $D L I$. Although the TCR V $\beta$ repertoire was markedly abnormal before DLI and persisted for several months after DLI, results shown in Fig. 3 suggest that at least some of these abnormally expanded populations begin to resolve by 3 mo after DLI. With longer observation, almost all of these abnormalities were found to resolve gradually. By 1 yr after DLI, all four patients demonstrated almost complete normalization of
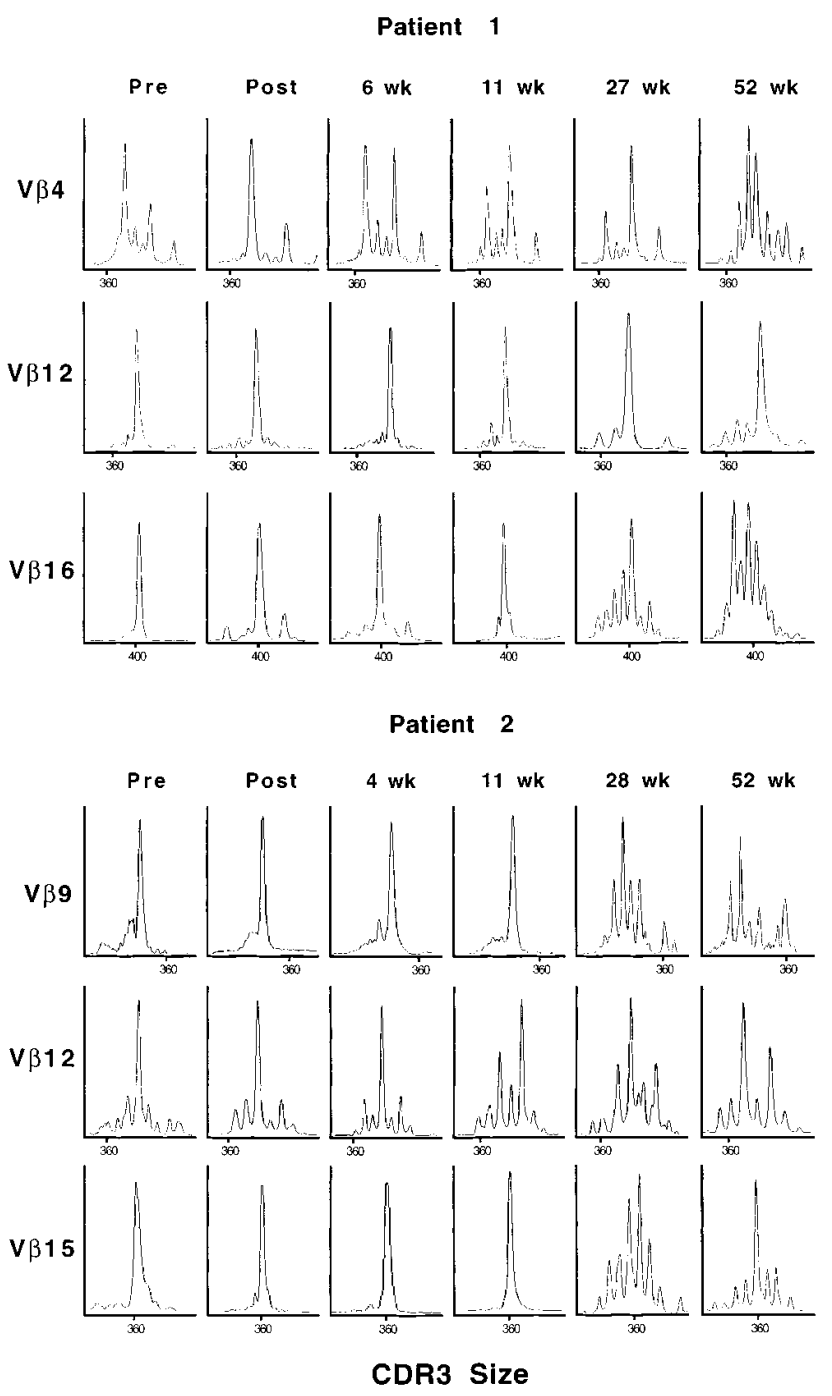

Figure 3. Evolution of clonal T cell populations after donor lymphocyte infusion. CDR3 profiles for $24 \mathrm{~V} \beta$ gene subfamilies were examined at periodic intervals for $1 \mathrm{yr}$ after donor lymphocyte infusion in four patients. The evolution of three representative CDR3 profiles for two patients are displayed at designated times either before or after infusion of CD4+ donor cells.

TCR V $\beta$ gene use, as well as normalization of CDR3 patterns for almost all V $\beta$ subfamilies. As shown in Fig. 4, relative use of TCR V $\beta$ subfamily genes was entirely normal for patient 1 at 62 wk after DLI. Before DLI, $19 \%$ of the V $\beta$ gene subfamilies in patient 1 were abnormally represented (Fig. 1). In patient $4,12 \%$ of the $\mathrm{V} \beta$ subfamilies were abnormally represented before DLI and a single gene (V $\beta 1$ ) was used by more than $60 \%$ of peripheral T cells. By 49 weeks after DLI, there had been a marked decrease in V $\beta 1$ use that was now represented in only $20 \%$ of peripheral T cells (Fig. 4). Further analysis of CDR3 patterns in these patients also demonstrated resolution of almost all clonal and oligoclonal patterns. As shown in Fig. 5, CDR3 patterns for the same samples from patients 1 and 4 examined in Fig. 4 also demonstrated normal polyclonal patterns for almost every $\mathrm{V} \beta$ subfamily. For patient 1 , all profiles demonstrated polyclonal patterns including normal 

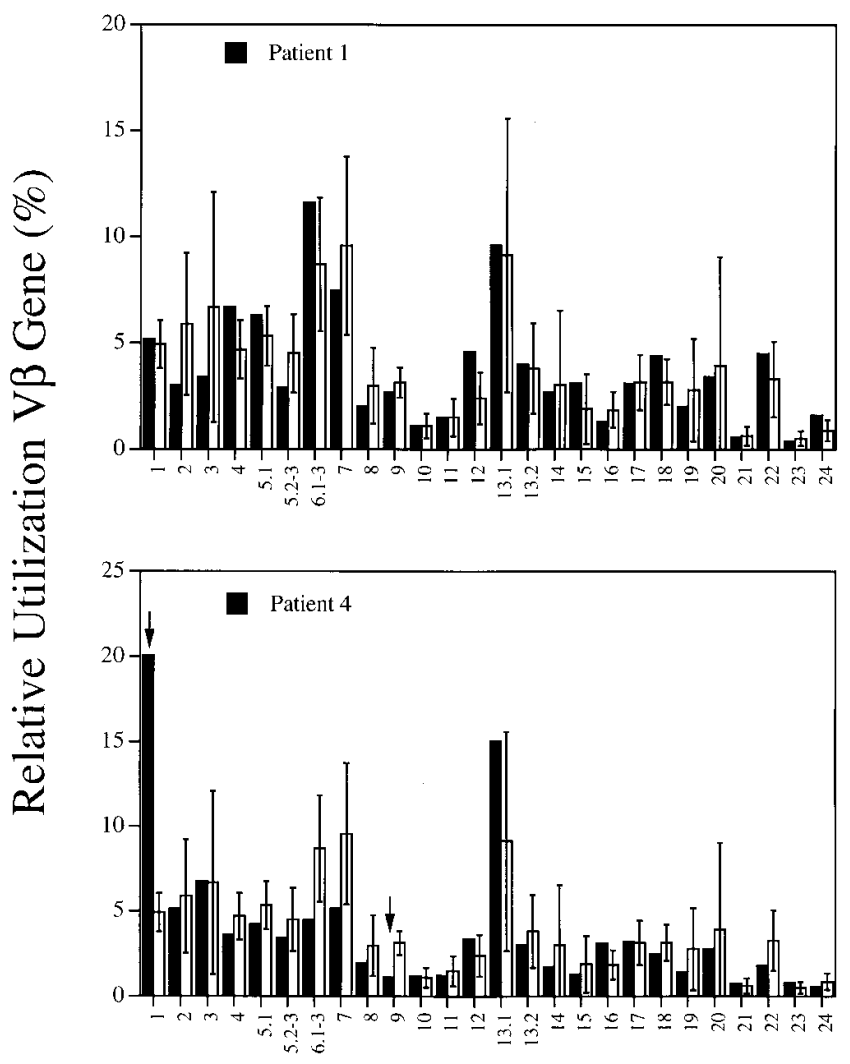

T Cell Receptor V $\beta$ Gene subfamily

Figure 4. $\mathrm{V} \beta$ gene representation in circulating $\mathrm{T}$ cells $\sim 1 \mathrm{yr}$ after donor CD4+ lymphocyte infusion. Results of $\mathrm{V} \beta$ gene analysis are shown for patient 1 at $62 \mathrm{wk}$ and for patient 4 at $49 \mathrm{wk}$ after treatment, and are compared to results obtained in 10 normal controls. Arrows indicate individual $\mathrm{V} \beta$ genes in patient 4 that are significantly different $(P<0.01)$ compared to normal controls. Black bars, patients; white bars, normals.

patterns in $\mathrm{V} \beta$ subfamilies that were previously underrepresented, as well as in $\mathrm{V} \beta$ subfamilies that previously demonstrated clonal expansions. In patient 4,21 of the $26 \mathrm{~V} \beta$ CDR3 profiles were abnormal before DLI (Fig. 2). By 49 wk after DLI, only V $\beta 1$ and V $\beta 17$ profiles continued to show predominately clonal patterns (Fig. 5).

Correlation of increased TCR V $\beta$ gene use with graft-versusleukemia activity. The four patients studied in this report were selected for further analysis of $\mathrm{T}$ cell repertoire because they each achieved complete cytogenetic and molecular remission after infusion of CD4+ donor T cells. Moreover, only one of the four patients (patient 3) developed clinically significant GVHD. Through serial quantitation of TCR V $\beta$ repertoire and analysis of CDR3 size patterns after DLI, we attempted to identify TCR V $\beta$ gene subfamilies representing an expansion of $T$ cells that could be correlated with the time of the cytogenetic response. In each patient, increased use of an individual TCR V $\beta$ gene subfamily was identified in the $2-4$-mo period after DLI in which these patients achieved cytogenetic remission. This temporal relationship between the percent circulating $\mathrm{T}$ cells expressing a single $\mathrm{V} \beta$ gene and the percent of marrow cells containing the $\mathrm{Ph}$ chromosome is shown for each patient in Fig. 6. The degree of $\mathrm{V} \beta$ gene amplification is variable from one patient to another, and ranges from 1.75 to 9.7 times. In patient 1 , the maximal representation of V $\beta 15$ preceded the cytogenetic response by $4 \mathrm{wk}$, but in the other three patients, maximal representation of these $\mathrm{T}$ cell populations in blood occurred 1-4 mo after $\mathrm{Ph}+$ cells could no longer be detected by cytogenetic analysis of marrow metaphases. In patients 2, 3, and 4, BCR-ABL-positive cells remained detectable by PCR for prolonged periods after they had achieved cytogenetic remission (Table I).

Further characterization of a putative GVL T cell clone in patient 1. Having identified changes in T cell repertoire associated with possible antileukemia activity, further studies were undertaken in one patient to determine whether these changes were due to expansion of clonal T cells, and to better characterize putative GVL clones. Serial analysis of the VB15 CDR3 pattern in patient 1 is illustrated in Fig. $7 \mathrm{~A}$. Before DLI, the CDR3 pattern for $\mathrm{V} \beta 15$ demonstrated a relatively polyclonal pattern. Two clonal peaks became evident at $6 \mathrm{wk}$ after DLI. A new clone migrating at a different position subsequently became a dominant clone in blood samples obtained at 11 and 19 wk after DLI. Although this clonal peak was still evident $27 \mathrm{wk}$ after DLI, a polyclonal pattern began to return at this time. By 62 wk after DLI, the V $\beta 15$ pattern was entirely polyclonal (see Fig. 5 A). These results suggested that the changes in TCR V $\beta$ repertoire associated with the GVL response were due to the expansion of clonal $\mathrm{T}$ cells that were not present in the patient before DLI.

To examine whether the clonal V $\beta 15$ CDR3 patterns shown in Fig. $7 A$ represented true expansion of individual $\mathrm{T}$ cell clones, the PCR-amplified CDR3 product from a representative sample was ligated into a cloning vector and transfected into Escherichia coli (Table II). 20 growing colonies were randomly selected, and the inserted DNA sequence was obtained from each colony. In patient 1 , the clonal expansion of V $\beta 15$ positive $\mathrm{T}$ cells at $11 \mathrm{wk}$ after DLI was confirmed by demonstrating the frequent recurrence of the same unique sequence in $64 \%$ of colonies analyzed. Moreover, the defined DNA sequence matched the predicted $\mathrm{V} \beta$ gene segment, and the specific $\mathrm{J}$ region and $\mathrm{C}$ region used in this clone could be identified. Unique CDR3 regions are generated through random nucleotide insertions and junctional deletions. DNA sequencing of the CDR3 region therefore also allows the design of unique complimentary synthetic oligonucleotides that can subsequently be used as specific probes for individual clones. As

\section{Table I. Patient Characteristics}

\begin{tabular}{|c|c|c|c|c|c|c|c|c|}
\hline Patient & $\begin{array}{l}\text { Age/ } \\
\text { sex }\end{array}$ & $\begin{array}{l}\text { GVHD } \\
\text { after } \\
\text { BMT }\end{array}$ & $\begin{array}{c}\text { CD4 cells } \\
\text { infused }\end{array}$ & $\begin{array}{c}\text { GVHD } \\
\text { after DLI }\end{array}$ & $\begin{array}{l}\text { BMT } \\
\text { to } \\
\text { relapse }\end{array}$ & $\begin{array}{l}\text { Relapse } \\
\text { to DLI }\end{array}$ & $\begin{array}{l}\text { DLI to cy- } \\
\text { togenetic } \\
\text { response }\end{array}$ & $\begin{array}{l}\text { DLI to } \\
\text { molecular } \\
\text { response }\end{array}$ \\
\hline & & & $10^{8} / \mathrm{kg}$ & & mo & mo & mo & mo \\
\hline 1 & $52 / \mathrm{M}$ & None & 0.3 & None & 12 & 22 & 3 & 3 \\
\hline 2 & $55 / \mathrm{F}$ & None & 0.3 & None & 27 & 17 & 5 & 9 \\
\hline 3 & $57 / \mathrm{F}$ & None & 1.5 & $\begin{array}{c}\text { Grade } 2 \\
\text { acute }\end{array}$ & 13 & 5 & 2 & 8 \\
\hline 4 & $34 / \mathrm{F}$ & None & 1.5 & $\begin{array}{l}\text { Minimal } \\
\text { chronic }\end{array}$ & 6 & 47 & 3 & 12 \\
\hline
\end{tabular}




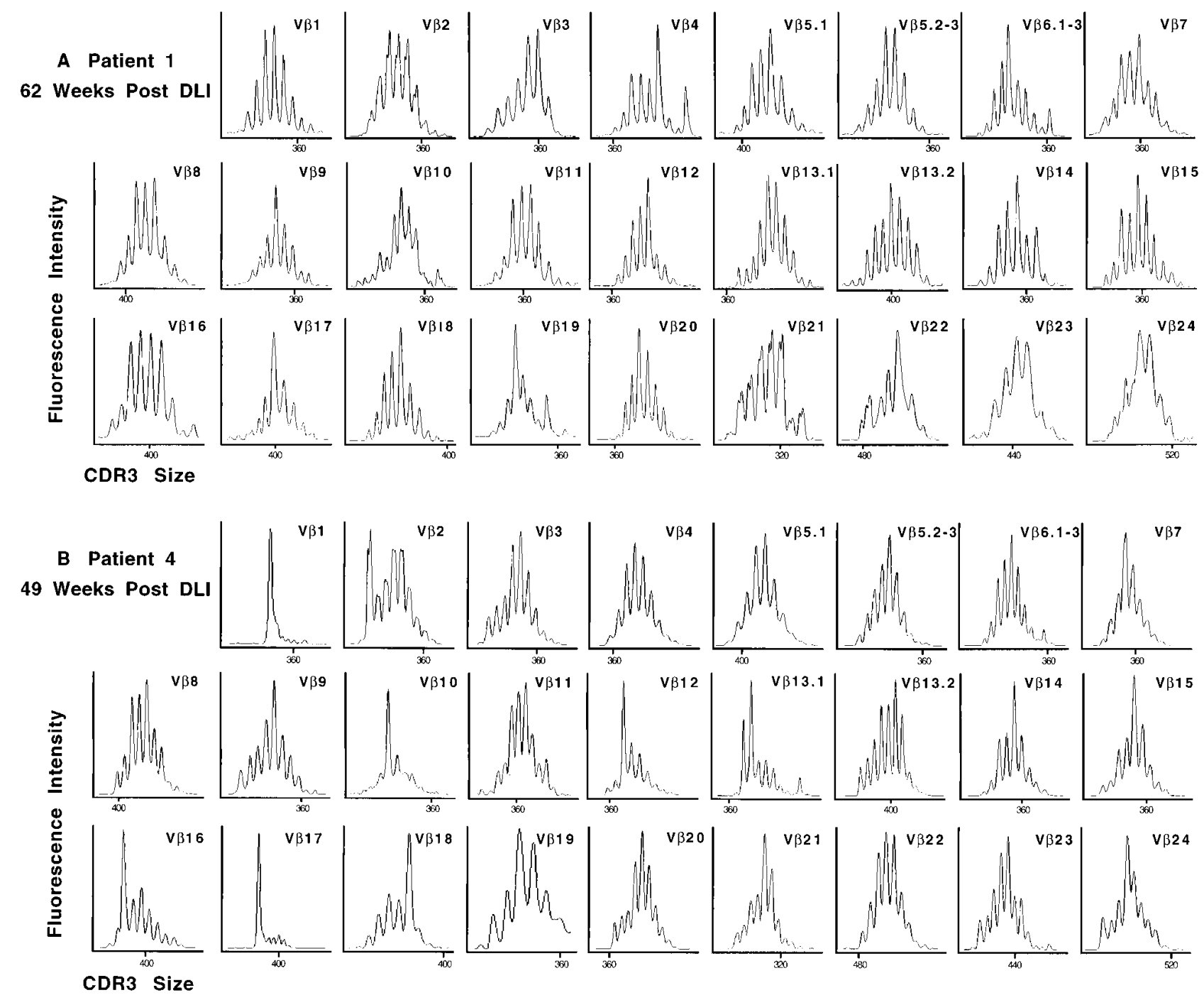

Figure 5. CDR3 size patterns for $24 \mathrm{~V} \beta$ gene subfamilies in circulating T cells $\sim 1 \mathrm{yr}$ after donor CD4+ lymphocyte infusion. CDR3 profiles are displayed for $\mathrm{T}$ cell samples from patient 1 at $62 \mathrm{wk}$ and from patient 4 at $49 \mathrm{wk}$ after donor lymphocyte infusion.

shown in Fig. $7 B$, PCR-amplified V $\beta 15$ DNA from serial blood samples was hybridized with the clone-specific oligonucleotide probe described in Methods. The specific target clone was not detectable in $\mathrm{T}$ cells obtained from an unrelated normal donor, the patient's donor, or the patient before DLI. The clone first became detectable $11 \mathrm{wk}$ after DLI, and persisted in all peripheral $\mathrm{T}$ cell samples for more than $1 \mathrm{yr}$. Of note, this included the sample obtained $62 \mathrm{wk}$ after DLI that appeared to have a normal polyclonal pattern by CDR3 size analysis. The target clone could no longer be detected in peripheral $\mathrm{T}$ cells 84 wk after DLI. Taken together, this additional characterization of changes in V $\beta 15$ expression after DLI confirmed that the increase in V $\beta 15$ use that occurred in association with the disappearance of leukemia cells in vivo was due to the appearance and expansion of a clonal $\mathrm{T}$ cell population whose presence persisted in the circulating $\mathrm{T}$ cell pool for at least $1 \mathrm{yr}$ after CML cells were no longer detectable by PCR. These findings are consistent with possible antileukemia activity, and further studies can now be undertaken to define the functional characteristics of this candidate GVL clone.

\section{Discussion}

Several recent reports have documented the clinical efficacy of DLI in patients with relapsed CML after allogeneic BMT. In the majority of patients, infusion of allogeneic lymphocytes from the same individual that had previously donated marrow results in complete disappearance of leukemic cells detectable by PCR as well as by cytogenetic and clinical criteria. Significantly, this response can be achieved without additional chemotherapy or other conventional therapy for CML. These clinical observations clearly demonstrate the importance of immunological mechanisms in eradicating leukemia after allogeneic BMT. Considerable evidence supports the hypothesis that elimination of residual leukemia is mediated primarily by donor T cells. Nevertheless, the precise immunologic mechanism that mediates this GVL effect in patients undergoing allogeneic BMT has not been identified. Moreover, most patients who respond to DLI also develop significant GVHD, and it has therefore been difficult to distinguish the GVL effect from GVHD. 

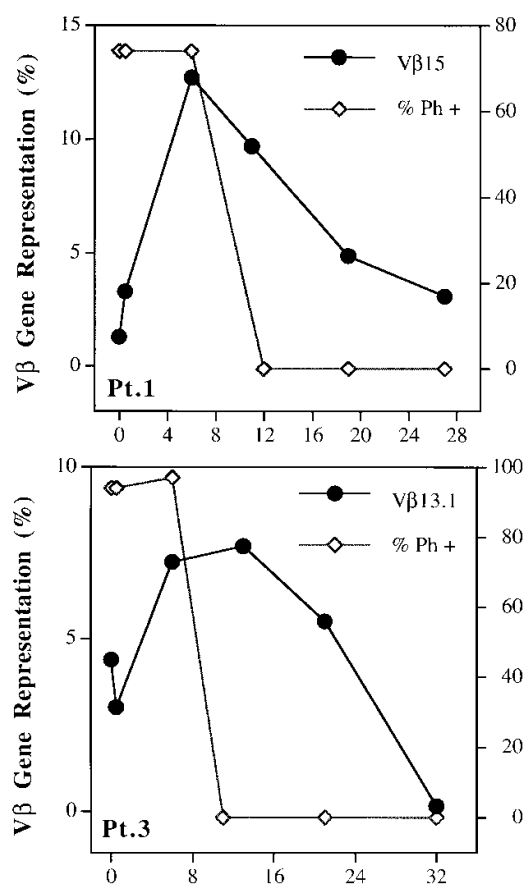

Weeks Post Lymphocyte Infusion
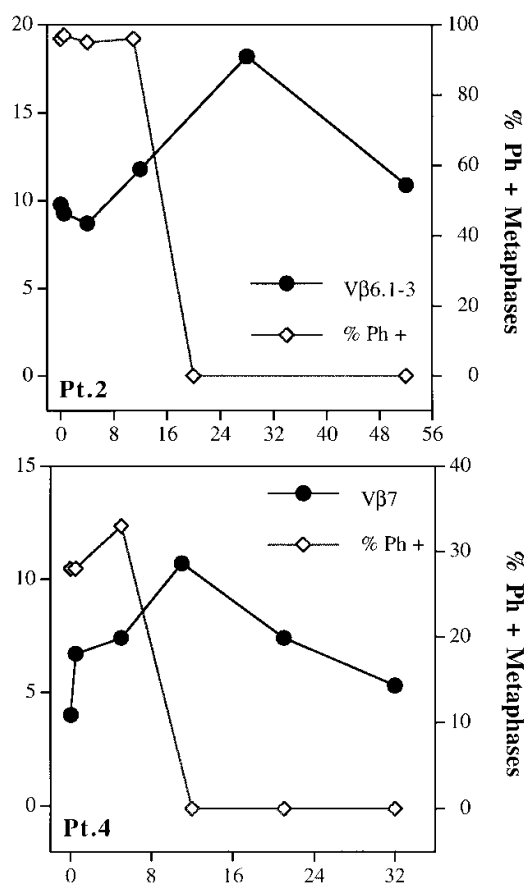

Weeks Post Lymphocyte Infusion
Figure 6. Temporal association of $\mathrm{V} \beta$ gene representation and presence of $\mathrm{Ph}+$ metaphases. The amplification of single $\mathrm{V} \beta$ gene subfamilies in circulating $\mathrm{T}$ cells is correlated with the disappearance of $\mathrm{Ph}+$ metaphases on sequential cytogenetic evaluation of bone marrow samples at defined intervals after donor lymphocyte infusion.
The present studies focused on a selected group of four patients with relapsed CML after allogeneic BMT. These patients were part of a larger study that examined the toxicity and efficacy of selected infusion of defined numbers of normal CD4 + T cells obtained from HLA-identical siblings. Patients 1 and 2 received $3 \times 10^{7} \mathrm{CD} 4+$ cells $/ \mathrm{kg}$, the lowest cell dose, and had no clinical or laboratory evidence of acute or chronic GVHD after DLI. Patients 3 and 4 received $1.5 \times 10^{8}$ CD4+ cells $/ \mathrm{kg}$, which was the highest cell dose examined in this clinical trial. Patient 3 developed Grade 2 hepatic acute GVHD and limited chronic GVHD, but patient 4 only developed minimal chronic GVHD. All four patients achieved a complete cytogenetic response that occurred between 2-5 mo after beginning DLI. BCR-ABL-positive cells subsequently became undetectable by PCR 3-12 mo after DLI. Overall, the clinical responses to donor CD4+ lymphocyte infusion in these four patients are representative of the other patients with CML entered on this clinical trial. This clinical trial is still ongoing, and additional patients are receiving $3 \times 10^{7} \mathrm{CD} 4+$ cells $/ \mathrm{kg}$ to better define the toxicities and antileukemia effects at this dose level. Thus far, the results of our trial appear to confirm the previous report by Giralt et al. (18), suggesting that elimination of donor CD8+ lymphocytes can successfully reduce the incidence of significant GVHD, the primary toxicity of DLI, without abro- gating the antileukemic effect in patients with relapsed CML. These findings support the hypothesis that donor CD8+ T cells are the primary effectors of GVHD, and also suggest that CD4+ donor T cells alone are capable of inducing an effective antileukemia response in vivo.

To characterize better the immunologic effects of allogeneic CD4 lymphocyte infusion, and to define the effects of treatment on the $\mathrm{T}$ cell compartment in vivo, we undertook a detailed analysis of $\mathrm{T}$ cell repertoire in the four selected patients described above. Blood samples obtained from patients before DLI and at periodic intervals for $1 \mathrm{yr}$ after DLI, as well as samples from their normal HLA-identical donors, were subjected to an identical analysis of TCR V $\beta$ use. The analysis of TCR V $\beta$ was based on the RT-PCR amplification of 24 distinct $V \beta$ subfamily genes. This method allows determination of relative use of each $\mathrm{V} \beta$ subfamily in peripheral blood $\mathrm{T}$ cells. Since the gene segment amplified for each TCR V $\beta$ gene subfamily encodes the hypervariable CDR3 region, this analysis also provides a distribution profile for each $\mathrm{V} \beta$ gene segment that is amplified. As a result, polyclonal $\mathrm{T}$ cell profiles are represented as multiple peaks forming a bell-shaped pattern, and can easily be distinguished from oligoclonal or clonal patterns that are represented as single discrete peaks. Previous reports have demonstrated that this molecular approach can be used

Table II. Junctional (CDR3 region) Sequences of Expanded V $\beta$ Subfamilies

\begin{tabular}{lccccr}
\hline V $\beta$ gene segment & Sample & Frequency & V Region & N-D $\beta$-N & J Region \\
\hline Pt.1 V $\beta 15$ & 11 wk after DLI & $64 \%$ & GCCACCAGT & GATG & GGGTTTTTG-J $\beta 1.4$
\end{tabular}

To confirm the clonal expansion of V 315 in patient 1 after DLI, PCR products were ligated into pCR2.1 TA cloning vector. After transfection, positive growing colonies were randomly picked and sequenced. Frequent occurrence of the same clone defined by his unique CDR3 sequence indicates a clonal expansion of $\mathrm{T}$ cells expressing this unique gene rearrangement. 

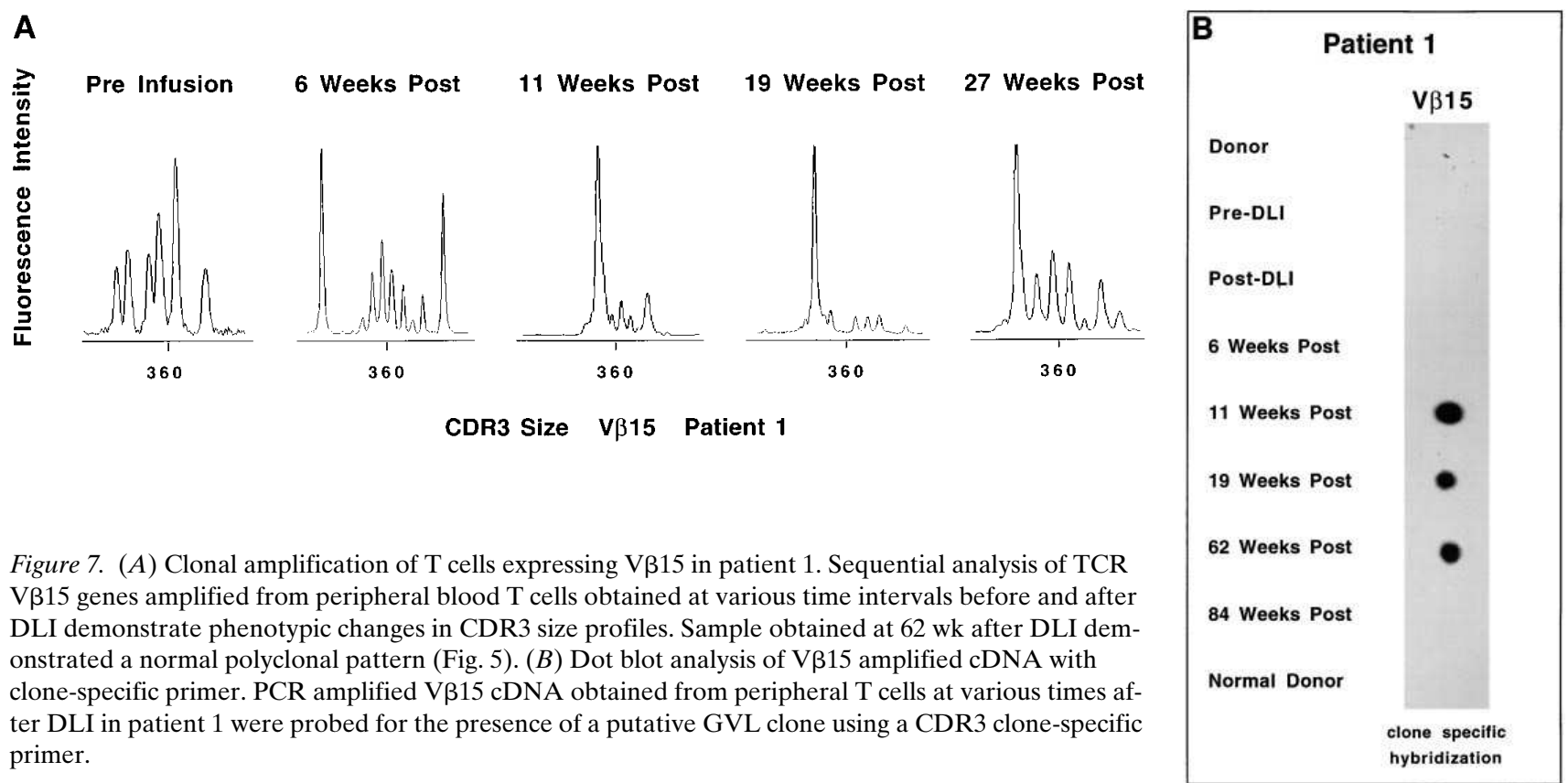

Figure 7. (A) Clonal amplification of T cells expressing V $\beta 15$ in patient 1 . Sequential analysis of TCR V 15 genes amplified from peripheral blood T cells obtained at various time intervals before and after DLI demonstrate phenotypic changes in CDR3 size profiles. Sample obtained at 62 wk after DLI demonstrated a normal polyclonal pattern (Fig. 5). (B) Dot blot analysis of V $\beta 15$ amplified cDNA with clone-specific primer. PCR amplified V $\beta 15$ cDNA obtained from peripheral T cells at various times after DLI in patient 1 were probed for the presence of a putative GVL clone using a CDR3 clone-specific primer.

CDR3 Size V $\beta 15$ Patient 1

hybridization

to define a variety of immune responses in vivo, and to identify changes in clonal $\mathrm{T}$ cell populations that could not be identified by other immunologic methods (36-42).

The first important observation of our analysis of TCR V $\beta$ repertoire was that all four patients displayed a markedly skewed $\mathrm{V} \beta$ repertoire in peripheral $\mathrm{T}$ cell samples obtained before DLI. This abnormal V $\beta$ repertoire was characterized by multiple clonotypic expansions as well as abnormally underused $\mathrm{V} \beta$ gene subfamilies in each patient. This result was unexpected since these patients had been transplanted $11 / 2,3$, $31 / 2$, and $41 / 2$ years before analysis, and all had relatively uneventful recoveries after BMT. Moreover, none had developed either acute or chronic GVHD, none had received immune suppressive medications, and there had been no evidence of chronic or recurrent infections. Clonal $\mathrm{T}$ cell expansions related to GVHD at early stages after BMT have been reported previously $(22,23)$. These expanded clones are most often CD8+ T cells (43). Some of these clones appear to have immunoregulatory functions (44), but others clearly have specificity for target antigens expressed on a variety of normal recipient cells. In patients who receive $\mathrm{T}$ cell-depleted allogeneic marrow, $\mathrm{T}$ cell diversity can remain abnormal for up to $2 \mathrm{yr}$ (27), but relatively normal $\mathrm{T}$ cell repertoire appears to reconstitute within $1 \mathrm{yr}$ after transplant in most patients (43). Although we have not yet undertaken a similar analysis in the early postBMT period, we have examined the TCR V $\beta$ repertoire in two patients with CML who have remained in remission for comparable time intervals after CD6 $\mathrm{T}$ cell-depleted allogeneic $\mathrm{BMT}$, and found that these individuals had relatively normal $T$ cell repertoire (data not shown). This finding suggests the possibility that the abnormal reconstitution of $\mathrm{T}$ cell repertoire in these patients preceded the relapse of CML, and may indicate that the abnormal $\mathrm{T}$ cell repertoire was one factor that could have allowed residual leukemia cells to progress in these individuals. Alternatively, it is also possible that the abnormal $\mathrm{T}$ cell repertoire was, through some unknown mechanism, caused by the relapsed leukemia. Although the mechanisms whereby malignant cells are capable of inhibiting immune function in vivo have not been clearly delineated, it is well known that patients with far advanced cancer have a variety of acquired immune deficiencies. Similarly, the presence of relapsed CML in the patients analyzed in our studies may have directly contributed to the marked abnormalities in TCR repertoire noted before DLI. Further studies to characterize prospectively reconstitution of TCR repertoire in larger numbers of patients after allogeneic BMT will be necessary to address this issue, and to allow us to identify possible causes of these abnormalities in $\mathrm{T}$ cell repertoire.

After the infusion of CD4+ donor lymphocytes, no immediate modification of the $\mathrm{T}$ cell repertoire was observed. All clonal and oligoclonal abnormalities persisted for a least $3 \mathrm{mo}$, but thereafter some of the abnormal patterns began to change with emergence of polyclonal CDR3 patterns that gradually replaced clonal peaks. Underused V $\beta$ gene subfamilies also began to demonstrate increased representation, and overrepresentation by single predominant V $\beta$ gene subfamilies gradually decreased. By 1 yr after DLI, V $\beta$ gene use was almost entirely normal. Almost all $24 \mathrm{~V} \beta$ gene subfamilies were normally represented in peripheral T cells in every patient, and almost all CDR3 profiles demonstrated normal polyclonal patterns. For example, before DLI, V $\beta$ gene use in patient 4 was markedly abnormal with a single TCR gene (V $\beta 1)$ represented in $65 \%$ of T cells. By 49 wk after DLI, V $\beta 1$ representation had gradually decreased to $20 \%$. This gradual normalization of V $\beta$ use occurred in all the patients, including patient 3 who was receiving immune suppressive steroids for the treatment of GVHD. The consistent but delayed improvement of $\mathrm{T}$ cell repertoire after DLI suggests that this treatment had a profound effect on global $\mathrm{T}$ cell immunity in these individuals. With normalization of $\mathrm{T}$ cell diversity, these patients should now have an improved ability to respond to a large variety of infectious agents. 
There are several potential mechanisms whereby infusion of mature CD4+ T cells might induce further differentiation and maturation of new $\mathrm{T}$ cells in vivo, resulting in normalization of $\mathrm{T}$ cell repertoire. It is also possible that this effect could be mediated by other cells within the CD8-depleted mononuclear cell population. The prolonged delay between the infusion of donor lymphocytes and the normalization of T cell repertoire suggests that DLI does not have a direct effect on the $\mathrm{T}$ cell repertoire. The patients described here are all adults, and do not have a functioning thymus. The demonstration that the $\mathrm{T}$ cell repertoire gradually matures in these patients suggests that extrathymic maturation pathways are present, and that these mechanisms are fully capable of regenerating normal levels of $\mathrm{T}$ cell diversity in vivo. Alternatively, it is also possible that normalization of TCR repertoire may have been indirectly influenced through elimination of the malignant cell population in vivo. If the abnormal TCR repertoire resulted from suppression of $\mathrm{T}$ cell immunity by CML cells, elimination of CML cells in vivo may have allowed normal T cell immunity to reconstitute. Although it is not possible to distinguish between these two alternative hypotheses at this time, further analysis of additional patients in whom infusion of CD4+ donor $\mathrm{T}$ cells have not resulted in elimination of leukemia cells in vivo may be informative. In either case, demonstration that a marked deficiency in $\mathrm{T}$ cell repertoire is capable of reconstitution in vivo may have important implications for the development of clinical approaches to improve $\mathrm{T}$ cell immunity in patients with other acquired immune deficiencies due to a variety of causes, including HIV infection.

Each of the four patients examined in this report demonstrated significant antileukemia activity after infusion of CD4+ donor $\mathrm{T}$ cells, and was able to achieve a complete remission documented by the gradual disappearance of cells expressing the BCR-ABL gene rearrangement in both blood and marrow. With a least $1 \mathrm{yr}$ follow-up after infusion of donor lymphocytes, none of these patients have any evidence of residual CML cells detected by sensitive nested PCR assays. The primary objective of these studies was to determine whether analysis of TCR V $\beta$ repertoire could identify specific T cell populations that were mediating this antileukemia activity. It was therefore of interest that we were able to identify at least one clonal $\mathrm{T}$ cell population that underwent expansion in peripheral blood coincident with elimination of $\mathrm{Ph}+$ cells in the blood and marrow of each patient. These candidate GVL clones used different TCR V $\beta$ genes, appeared at different times after DLI, and persisted for variable periods. Thus, even though the serial analysis of changes in TCR repertoire allowed us to identify these clonal $\mathrm{T}$ cell populations, further studies will be necessary to isolate these cells and to determine their specificity. This functional analysis will be necessary to determine whether or not these candidate $\mathrm{T}$ cell clones are, in fact, mediators of antileukemia immunity in vivo. Although these studies will likely be difficult, they can now be guided by our ability to focus on relatively small numbers of circulating $T$ cells expressing defined TCR V $\beta$ genes, and unique $\mathrm{V} \beta$ gene rearrangements.

In previous clinical studies that have examined the immunologic mechanisms capable of mediating a GVL response, it has been very difficult to distinguish between GVL and GVHD. These studies have successfully identified $\mathrm{T}$ cell clones specific for different alloantigens expressed on a variety of normal tissues, and have also demonstrated that leukemia cells expressing these target antigens are susceptible to these potent effector cells $(16,37)$. These results have therefore identified immunologic mechanisms whereby $\mathrm{T}$ cells capable of mediating GVHD are also able to induce GVL. They have not, however, identified potential mechanisms for inducing GVL independently of GVHD. Although the current studies were restricted to four patients who achieved complete remission of their CML, only one of these patients (patient 3 ) demonstrated significant evidence of GVHD after infusion of CD4+ donor lymphocytes. This clinical result strongly suggests that DLI in these individuals has induced an immune response directed against antigens selectively expressed by CML cells, and not also widely expressed on recipient tissues. Candidate antigens might be products of the CML-specific BCRABL translocation, or other leukemia-specific antigens that have not yet been identified. Alternatively, the target antigens of this response might be minor histocompatibility antigens selectively expressed on recipient hematopoietic elements (45) in addition to leukemic cells. Further studies will be necessary to define the target antigens of the GVL responses in these individuals, and to determine whether this effect is, in fact, an example of tumor-specific immunity. Regardless of whether the targets of these responses are found to be leukemia-specific or not, it is likely that the characterization of the target antigens for these responses will be useful for the development of new clinical strategies to induce and amplify the effectiveness of these cells in vivo.

\section{Acknowledgments}

This work was supported by National Institutes of Health grant AI29530.

\section{References}

1. Antin, J.H. 1993. Graft-versus-leukemia: no longer an epiphenomenon. Blood. 82:2273-2277.

2. Kolb, H.J., J. Mittermuller, C. Clem, E. Holler, G. Ledderose, G. Brehm, M. Heim, and W. Wilmanns. 1990. Donor leukocyte transfusions for treatment of recurrent chronic myelogenous leukemia in marrow transplant patients. Blood. 76:2462-2465.

3. Kolb, H.J., A. Schattenberg, J.M. Goldman, B. Hertenstein, N. Jacobsen, W. Arcese, P. Ljungman, A. Ferrant, L. Verdonck, and D. Niederwieser. 1995. Graft-versus-leukemia effect of donor lymphocyte ransfusions in marrow grafted patients. European Group for Blood and Marrow Transplantation Working Party Chronic Leukemia. Blood. 86:2041-2050.

4. Porter, D.L., M.S. Roth, C. McGarigle, J.L. Ferrara, and J.H. Antin. 1994. Induction of graft-versus-host disease as immunotherapy for relapsed chronic myeloid leukemia. N. Engl. J. Med. 330:100-106.

5. Slavin, S., E. Naparstek, A. Nagler, A. Ackerstein, S. Samuel, J. Kapelushnik, C. Brautbar, and R. Or. 1996. Allogeneic cell therapy with donor peripheral blood cells and recombinant human interleukin-2 to treat leukemia relapse after allogeneic bone marrow transplantation. Blood. 87:2195-2204.

6. Collins, R., O. Shpilberg, W. Drobyski, D. Porter, S. Giralt, R. Champlin, S. Goodman, S. Wolff, C. Verfaillie, and A. List. 1997. Donor leukocyte infusions in 140 patients with relapsed malignancy after allogeneic bone marrow transplantation. J. Clin. Oncol. 15:433-444.

7. Marmont, A.M. 1993. The graft versus leukemia (GVL) effect after allogeneic bone marrow transplantation for chronic myelogenous leukemia (CML). Leuk. Lymphoma. 11:221-226.

8. Horowitz. M.M., R.P. Gale, P.M. Sondel, J.M. Goldman, J. Kersey, H.J. Kolb, A.A. Rimm, O. Ringden, C. Rozman, and B. Speck. 1990. Graft-versusleukemia reactions after bone marrow transplantation. Blood. 75:555-562.

9. Giralt, S.A., and R.E. Champlin. 1994. Leukemia relapse after allogeneic bone marrow transplantation: a review. Blood. 84:3603-3612.

10. Goldman, J.M., R.P. Gale, M.M Horowitz, J.C. Biggs, R.E. Champlin, E. Gluckman, R.G. Hoffmann, S.J. Jacobsen, A.M. Marmont, and P.B. McGlave. 1988. Bone marrow transplantation for chronic myelogenous leukemia in chronic phase: increased risk for relapse associated with T-cell depletion. Ann. Intern. Med. 108:806-814.

11. Marmont, A.M., M.M. Horowitz, R.P. Gale, K. Sobocinski, R.C. Ash, 
D.W. van Bekkum, R.E. Champlin, K.A. Dicke, J.M. Goldman, and R.A. Good. 1991. T-cell depletion of HLA-identical transplants in leukemia. Blood. 78:2120-2130

12. Weiden, P., K. Sullivan, N. Flournoy, R. Storb, and E. Thomas. 1981. Anti-leukemic effect of chronic graft-versus-host disease: contribution to improved survival after allogeneic marrow transplantation. N. Engl. J. Med. 304: 1529-1533.

13. Weiden, P.L., M.S. Flournoy, E.D. Thomas, R. Prentice, A. Fefer, C.D. Buckner, and R. Storb. 1979. Anti-leukemic effect of graft-versus-host-disease in human recipients of allogeneic-marrow grafts. N. Engl. J. Med. 300:10681073.

14. Weisdorf, D.J., M.E. Nesbit, N.K. Ramsay, W.G. Woods, A.I. Goldman, T.H. Kim, D.D. Hurd, P.B. McGlave, and J.H. Kersey. 1987. Allogeneic bone marrow transplantation for acute lymphoblastic leukemia in remission: prolonged survival associated with acute graft-versus-host disease. J. Clin. Oncol. 5:1348-1355

15. Gaschet, J., M.A. Trevino, M. Cherel, R. Vivien, A. Garcia-Sahuquillo, M.M. Hallet, M. Bonneville, J.L. Harrousseau, R. Bragado, N. Milpied, and H. Vie. 1996. HLA-target antigens and T-cell receptor diversity of activated T cells invading the skin during acute graft-versus-host disease. Blood. 87:2345-2353.

16. Faber, L.M., S.A.P. van Luxemburg-Heijs, W.F.J. Veenhof, R. Willemze, and J.H.F. Falkenburg. 1995. Generation of CD4+ cytotoxic T-lymphocyte clones from a patient with severe graft-versus-host disease after allogeneic bone marrow transplantation: implications for graft-versus-leukemia reactivity. Blood. 86:2821-2828.

17. Mackinnon, S., E.B. Papadopoulos, M.H. Carabasi, L. Reich, N.H. Collins, F. Boulad, H. Castro-Malaspina, B.H. Childs, A.P. Gillio, and N.A. Kernan. 1995. Adoptive immunotherapy evaluating escalating doses of donor leukocytes for relapse of chronic myeloid leukemia after bone marrow transplantation: separation of graft-versus-leukemia responses from graft-versus-host disease. Blood. 86:1261-1268.

18. Giralt, S., J. Hester, Y. Huh, C. Hirsch-Ginsberg, G. Rondon, D. Seong, M. Lee, J. Gajewski, K. Van Besien, and I. Khouri. 1995. CD8-depleted donor lymphocyte infusion as treatment for relapsed chronic myelogenous leukemia after allogeneic bone marrow transplantation. Blood. 86:4337-4343.

19. Mehta, J. 1993. Graft-versus-leukemia reactions in clinical bone marrow transplantation. Leuk. Lymphoma. 10:427-432

20. Rowen, L., B.F. Koop, and L. Hood. 1996. The complete 685-kilobase DNA sequence of the human $\beta$ T cell receptor locus. Science (Wash. DC). 272: $1755-1762$

21. Yamanaka, K., W.W. Kwok, E.M. Mickelson, S. Masewicz, F. Smith, and G.T. Nepom. 1993. Selective T-cell-receptor gene usage in allorecognition and graft-versus-host disease. Transplantation (Baltimore). 55:1167-1175.

22. Dietrich, P.Y., A. Caignard, A. Diu, C. Genevee, J.L. Pico, M. HenryAmar, J. Bosq, E. Angevin, F. Triebel, and T. Hercend. 1992. Analysis of T-cell receptor variability in transplanted patients with acute graft-versus-host disease. Blood. 80:2419-2424.

23. Dietrich, P.Y., A. Caignard, A. Lim, V. Chung, J.L. Pico, C. Pannetier, P. Kourilsky, T. Hercend, J. Even, and F. Triebel. 1994. In vivo T-cell clonal amplification at time of acute graft-versus-host disease. Blood. 84:2815-2820.

24. Kubo, K., K. Yamanaka, H. Kiyoi, H. Fukutani, M. Ito, R. Hayakawa, R. Ohno, and T. Naoe. 1996. Different T-cell receptor repertoires between lesions and peripheral blood in acute graft-versus-host disease after allogeneic bone marrow transplantation. Blood. 87:3019-3026.

25. Liu, X., V. Chesnokova, S.J. Forman, and D.J. Diamond. 1996. Molecular analysis of $\mathrm{T}$-cell receptor repertoire in bone marrow transplant recipients: evidence for oligoclonal T-cell expansion in graft-versus-host disease. Blood. 87:3032-3044.

26. DeBruyne, L.A., J.P. Lynch, A. Baker, R. Florn, G.M. Deeb, R.I Whyte, and D.K. Bishop. 1996. Restricted V $\beta$ usage by T cells infiltrating rejecting human lung allografts. J. Immunol. 156:3493-3500.

27. Roux, E., C. Helg, F. Dumont-Girard, B. Chapuis, M. Jeannet, and E. Roosnek. 1996. Analysis of T-cell repopulation after allogeneic bone marrow transplantation: significant differences between recipients of T-cell depleted and unmanipulated grafts. Blood. 87:3984-3992.

28. Soiffer, R.J., C. Murray, P. Mauch, K.C. Anderson, A.S. Freedman, S.N.
Rabinowe, T. Takvorian, M.J. Robertson, N. Spector, and R. Gonin. 1992. Prevention of graft-versus-host disease by selective depletion of CD6-positive T lymphocytes from donor bone marrow. J. Clin. Oncol. 10:1191-2000.

29. Delage, R., R.J. Soiffer, K. Dear, and J. Ritz. 1991. Clinical significance of bcr-abl gene rearrangement detected by polymerase chain reaction after allogeneic bone marrow transplantation in chronic myelogenous leukemia. Blood. 78:2759-2767.

30. Pichert, G., D. Roy, R. Gonin, E. Alyea, R. Belanger, M. Gyger, C. Perreault, Y. Bonny, I. Lerra, and C. Murray. 1995. Distinct patterns of minimal residual disease associated with graft-versus-host disease after allogeneic bone marrow transplantation for chronic myelogenous leukemia. J. Clin. Oncol. 13: 1704-1713.

31. Choi, Y.W., B. Kotzin, L. Herron, J. Callahan, P. Marrack, and J. Kappler. 1989. Interaction of Staphylococcus aureus toxin superantigens with human T cells. Proc. Natl. Acad. Sci. USA. 86:8941-8945.

32. Genevee, C., A. Diu, J. Nierat, A. Caignard, P.Y. Dietrich, L. Ferradini, S. Roman-Roman, F. Triebel, and T. Hercend. 1992. An experimentally validated panel of subfamily-specific oligonucleotide primers (V alpha 1-w29/V beta 1-w24) for the study of human T cell receptor variable V gene segment usage by polymerase chain reaction. Eur. J. Immunol. 22:1261-1269.

33. Puisieux, I, J. Even, C. Pannetier, F. Jotereau, M. Favrot, and P. Kourilsky. 1994. Oligoclonality of tumor-infiltrating lymphocytes from human melanomas. J. Immunol. 153:2807-2818.

34. Pannetier, C., M. Cochet, S. Darche, A Casrouge, M. Zoller, and P. Kourilsky. 1993. The sizes of the CDR3 hypervariable regions of the murine T-cell receptor beta chains vary as a function of the recombined germ-line segments. Proc. Natl. Acad. Sci. USA. 90:4319-4323.

35. Gorski, J., M. Yassai, X. Zhu, B. Kissela, C. Keever, and N. Flomenberg. 1994. Circulating T cell repertoire complexity in normal individuals and bone marrow recipients analyzed by CDR3 size spectratyping. Correlation with immune status. J. Immunol. 152:5109-5119.

36. Hingorani, R., I.-H. Choi, P. Akolkar, B. Gulwani-Akolkar, R. Pergolizzi, J. Silver, and P. Gregersen. 1993. Clonal predominance of T cell receptors within the CD8+ CD45RO+ subset in normal human subjects. J. Immunol. 151:5762-5769.

37. Gaschet, J., A. Lim, L. Liem, R. Vivien, M.M. Hallet, J.L. Harousseau, J. Even, E. Goulmy, M. Bonneville, N. Milpied, and H. Vie. 1996. Acute graft versus host disease due to $\mathrm{T}$ lymphocytes recognizing a single HLADPB1*0501 mismatch. J. Clin. Invest. 98:100-107.

38. thor Straten, P., J.C. Becker, T. Seremet, E.B. Broker, and J. Zeuthen. 1996. Clonal T cell responses in tumor infiltrating lymphocytes from both regressive and progressive regions of primary human malignant melanoma. $J$. Clin. Invest. 98:279-284.

39. Akatsuka, Y., C. Cerveny, and J. Hansen. 1996. T cell receptor clonal diversity following allogeneic marrow grafting. Hum. Immunol. 48:125-134.

40. Roux, E., C. Helg, B. Chapuis, M. Jeannet, and E. Roosnek. 1996. T-cell repertoire complexity after allogeneic bone marrow transplantation. Hum. Immunol. 48:135-138.

41. Callan, M.F.C., N. Steven, P. Krausa, J.D.K. Wilson, P.A.H. Moss, G.M. Gillespie, J.I. Bell, A.B. Rickinson, and A.J. McMichael. 1996. Large clonal expansions of CD8+ T cells in acute infectious mononucleosis. Nat. Med. 2:906-911.

42. Akolkar, P., B. Gulwani-Akolkar, R. Pergolizzi, R. Bigler, and J. Silver. 1993. Influence of HLA genes on T cell receptor V segment frequencies and expression levels in peripheral blood lymphocytes. J. Immunol. 150:2761-2773.

43. Masuko, K., S. Kato, M. Hagihara, F. Tsuchida, Y. Takemoto, K. Izawa, T. Kato, S. Yamamori, Y. Mizushima, and K. Nishioka. 1996. Stable clonal expansion of T cells induced by bone marrow transplantation. Blood. 87:789-799.

44. Gorochov, G., P. Debre, V. Leblond, B. Sadat-Sowti, F. Sigaux, and B. Autran. 1994. Oligoclonal expansion of CD8+ CD57+ T cells with restricted T-cell receptor beta chain variability after bone marrow transplantation. Blood. 83:587-595.

45. Goulmy, E., R. Schipper, J. Pool, E. Blokland, J.H. Falkenburg, J. Vossen, A. Grathwohl, G. B. Vogelsang, H.C. van Houwelingen, and J.J. van Rood. 1996. Mismatches of minor histocompatibility antigens between HLA-identical donors and recipients and the development of graft-versus-host disease after bone marrow transplantation. N. Engl. J. Med. 334:281-285. 